\title{
Organic Farming Research in India: Present Status and Way Forward
}

\author{
K. A. Gopinath ${ }^{1 *}$, Ch. Srinivasa Rao ${ }^{1}$, A. V. Ramanjaneyulu ${ }^{2}$, M. Jayalakshmi ${ }^{1}$, G. Ravindra Chary ${ }^{1}$ and G. Venkatesh ${ }^{1}$ \\ ${ }^{1}$ Central Research Institute for Dryland Agriculture, Hyderabad (500 059), India \\ ${ }^{2}$ Professor Jayashankar Telangana State Agricultural University, Hyderabad (500 030), India
}

\section{Corresponding Author}

K. A. Gopinath

e-mail: gopinath_ka@yahoo.com
Article History

Article ID: IJEP103

Received in $6^{\text {th }}$ June, 2016

Received in revised form $19^{\text {th }}$ July, 2016

Accepted in final form $1^{\text {st }}$ August, 2016

\begin{abstract}
Organic farming is a knowledge intensive system and has been developed by practitioners themselves over the years. Organic farming is native to India. The farmers of ancient India are known to have evolved nature friendly farming systems and practices such as mixed farming, mixed cropping and crop rotation. The first "scientific" approach to organic farming can be quoted back to the Vedas of the "Later Vedic Period", 1000 BC to 600 BC. There has been significant increase in the area under certified organic farming during the last 10 years. With less than 42,000 ha under certified organic farming during 2003-04, the area under organic farming grew by almost 25 fold, during the next 5 years, to 1.2 million ha during 2008-09. Organic farming is one such system which provides healthy and safe food without ecological harm. Hence, the Government started promoting organic farming through various schemes like National Project on Organic Farming (NPOF), National Horticulture Mission (NHM), Horticulture Mission for North East \& Himalayan States (HMNEH), National Project on Management of Soil Health and Fertility (NPMSH\&F) and Rashtriya Krishi Vikas Yojana (RKVY). The interest of several States in promoting organic farming indicates that organic agriculture is being viewed as a precursor to dynamic change for an otherwise stagnant agricultural sector. Despite the initiatives and rapid progress, apprehension about the economic viability and environmental and human health benefits of organic farming continue to bother agricultural researchers and policy makers.
\end{abstract}

Keywords: Organic farming, Vrikshayurveda, Rashtriya Krishi Vikas Yojana

\section{Introduction}

Organic farming is native to India. The farmers of ancient India are known to have evolved nature friendly farming systems and practices such as mixed farming, mixed cropping and crop rotation. The first "scientific" approach to organic farming can be quoted back to the Vedas of the "Later Vedic Period", 1000 BC to 600 BC (Randhawa, 1986; and Pereira, 1993). The essence is to live in partnership with, rather than exploit, nature. In this regard, the "Vrikshayurveda" (Science of plants), the "Krishisastra" (Science of agriculture) and the "Mrugayurveda" (Animal Science) are the main works (Mahale and Soree, 1999). Organic movement owes its origin primarily to the work of Sir Albert Howard, often referred to as the father of modern organic agriculture, who believed that a shift from nature's methods of crop production to adoption of newer methods leads to the loss of soil fertility (Howard, 1943). From 1905 to 1924, he worked as an agricultural adviser in India, where he documented traditional Indian farming practices and came to regard them as superior to his conventional agriculture science. His research and further development of these methods is recorded in his writings, notably in his book,
An Agricultural Testament. It is this pioneering work which sowed the seeds of organic movement in India, placing greater emphasis on the use of compost and other organic sources of plant nutrients to the total exclusion of chemical fertilizers.

There has been significant increase in the area under certified organic farming during the last 10 years. With less than 42,000 ha under certified organic farming during 2003-04, the area under organic farming grew by almost 25 fold, during the next 5 years, to 1.2 million ha during 2008-09. Later, however, the area under certified organic farming has fluctuated between 0.78-1.1 million ha. Presently, about 0.5 million ha area is under certified organic cultivation and India ranks $16^{\text {th }}$ in terms of total land under organic cultivation and $92^{\text {nd }}$ position for agriculture land under organic crops to total farming area (Willer and Julia, 2014). During 2012-13, India had the largest number of organic producers of about 0.6 million and accounted for 1.24 million tons of certified organic produce. India exported 135 products during 2013-14 with the total volume of $194088 \mathrm{MT}$ including $16322 \mathrm{MT}$ organic textiles. The organic agri-export realization was around 403 million US \$ including 183 US \$ organic textiles registering a $7.73 \%$ 
growth over the previous year.

\section{Research on Organic Farming}

Keeping in view the ever increasing negative impacts on human health and ecology due to present commercial farming systems following intensive usage of synthetic inputs, researches and policy makers are forced to find out alternative way of farming (Ramanjaneyulu et al., 2013). Organic farming is one such system which provides healthy and safe food without ecological harm. Hence, the Government started promoting organic farming through various schemes like National Project on Organic Farming (NPOF), National Horticulture Mission (NHM), Horticulture Mission for North East \& Himalayan States (HMNEH), National Project on Management of Soil Health and Fertility (NPMSH\&F) and Rashtriya Krishi Vikas Yojana (RKVY). In addition, government agencies of many States are involved in either promotion of organic programmes or formulation of organic policies. The interest of several States in promoting organic farming indicates that organic agriculture is being viewed as a precursor to dynamic change for an otherwise stagnant agricultural sector.

Despite the initiatives and rapid progress, apprehension about the economic viability and environmental and human health benefits of organic farming continue to bother agricultural researchers and policy makers. Indian Council of Agricultural Research (ICAR) initiated a network project on organic farming in 2003-04 under the Project Directorate for Farming Systems Research (PDFSR), Modipuram to study productivity, profitability, sustainability, quality and inputuse-efficiencies of different crops and cropping systems under organic farming in different agro-ecological regions. Thirteen research stations from all over the country are participating in the project. Similarly, The All India Network Project on Biofertilizers (AINPB) under the Indian Institute of Soil Science, Bhopal is mandated to formulate and testing of mixed biofertilizers for diverse cropping systems and to improve biofertilizer technology with particular reference to quality, carriers, consortia and delivery systems. The University of Agricultural Sciences, Dharwad (Karnataka) established the Institute of Organic Farming in 2006 with an objective to cater to the needs of organic farmers and other stakeholders in the State. Similarly, in 2006, the University of Agricultural Sciences, Bangalore (Karnataka) established the Organic Farming Research Center at Shimoga and Organic Farming Research Station at Naganahalli (near Mysore) to scientifically validate and analyze the claims of organic agricultural produce and help popularize it among farmers. The Department of Organic Agriculture was established by the CSKHPKV, Palampur (Himachal Pradesh) in 2009 with a specific mandate to promote organic farming in the State. In addition, many ICAR Institutes and State Agricultural Universities have initiated a number of research projects or centers to develop location-specific organic farming modules.

The major findings of some of these studies (both on-farm and on-station) are:

- Typically farmers experience some loss in yields after discarding synthetic inputs and converting their operations from the conventional systems to organic production. Before restoration of full biological activity in soils, pest suppression and fertility problems are common. The degree of yield loss varies and depends on inherent biological attributes of the farm, the farmers' expertise, the extent to which synthetic inputs were used under previous management and also the state of natural resources. For example, the grain yield of wheat was markedly lower under organic management (36-65\% and $23-54 \%$ less in the first and second year of transition, respectively) than with the conventional treatment (Gopinath et al., 2008). Similarly, the yields of bell pepper and french bean under organic management were significantly lower (25.2-45.9\% and 29.5-46.2\%, respectively) than under conventional management during a 2 -year conversion period (Gopinath et al., 2011).

- After the conversion period, organic agriculture usually produces similar or significantly higher yields and requires less external inputs compared to conventional agriculture. Several region-specific cropping systems have been identified through network project on organic farming, which performed either better than or at par with conventional cropping in terms of yield and economics (Gill and Prasad, 2009).

- A survey conducted during 2008-09 in Maharashtra, Karnataka, Tamil Nadu (including Puducherry), Kerala and Uttarakhand involving 50 certified organic farms and 50 comparable conventional farms revealed that organic farming, in spite of the reduction in crop productivity by $9.2 \%$, provided higher net profit to farmers by $22.0 \%$ compared to conventional farming. This was mainly due to the availability of premium price (20-40\%) for the certified organic produce and reduction in the cost of cultivation by $11.7 \%$. In cases, where such premium prices were not available and the cost of cultivation was higher primarily due to purchased off-farm inputs, organic farming was not found economically feasible (Ramesh et al., 2010). Similarly, in another study conducted in Madhya Pradesh, Tamil Nadu and Uttarakhand involving 120 certified organic farms and 120 conventional farms, it was found that organic farming reduced the input cost without affecting the net margin in all three states. Organic farming in most cases was comparable to conventional farming in terms of yield in Uttarakhand and Tamil Nadu. However, the yield was lower under organic farming in Madhya Pradesh where farms focused on cash crop production (cotton). While yield of rice and wheat generally was lower under the organic systems, yield from intercropping food crops was generally higher (Panneerselvam et al., 2011).

- A comparison of 60 organic and 60 conventional cotton farms in Central India revealed that the average cotton yields in organic fields were 4-6\% higher compared to conventional farms. The variable production costs were $13-20 \%$ lower in 
organic cotton mainly due to $40 \%$ lower costs for inputs. Due to slightly higher cotton yields, the $20 \%$ organic price premium and lower production costs, gross margins in organic cotton fields were $30-43 \%$ higher. Further, many farmers observed that they need less rounds of irrigation and that the organic cotton can sustain longer periods of drought (Eyhorn et al., 2009).

- A number of studies conducted across the country have clearly established that soil quality improves under organic management in terms of various parameters, viz. physical, chemical, biological properties, availability of macro- and micronutrients, indicating an enhanced soil health and sustainability of crop production in organic farming systems (Saha et al., 2008; Gopinath et al., 2011; Surekha et al., 2013; and Dubey and Datt, 2014).

- In an extensive survey involving 376 farmers (199 organic and 177 inorganic farmers) in seven states (Himachal Pradesh, Uttarakhand, Maharashtra, Tamilnadu, Karnataka, Kerala and Rajasthan), the cost-benefit analysis indicated favourable economics of organic farming in India (Partap and Vaidya, 2009). Farmers in 5 out of 7 states were better placed as far as organic farming is concerned. The returns were higher in Himachal Pradesh, Uttarakhand, Karnataka, Maharashtra and Rajasthan.

It is evident from limited short-term research findings that many crops respond better to organic management particularly after an initial conversion period of 2-3 years. Organic farming can significantly contribute to improving the livelihoods of small holders as it generates higher incomes and involves less risk.

\section{Way Forward}

Organic farming is a knowledge intensive system and has been developed by practitioners themselves over the years. A number of authors have reflected on past difficulties faced by scientists working on organic farming and the acceptance of both the research and the scientists themselves in the wider research community. Although many ICAR institutes and state agricultural universities have initiated research on organic farming, the literature is dominated by comparisons of organic and conventional agriculture. There are several researchable issues and more are likely to emerge as researchers begin to explore it. Some of these include:

- Eco-friendly and economical organic packages in various field crops, commercial crops, vegetables, spices and condiments, aromatic crops and other horticultural crops keeping in view the export standards of various countries are to be developed and popularized.

- Multidisciplinary research approach is to be strictly followed for development of organic packages

- Delineation of the potential areas or zones including hill and tribal areas for organic farming by identifying contiguous blocks of areas with little or no chemical input use and where productivity can be enhanced by using permitted inputs to enable group certification to farmers.

- Carry out a country wide survey or inventorisation of areas in arid, semi-arid and dry sub humid regions about the level of chemical input use, productivity in selected commodities which have potential to fetch price premiums in international markets.

- Survey, documentation and critical evaluation of indigenous technological knowledge on organic farming.

- Inter-disciplinary and location-specific research has to be taken up for development of package of practices for organic farming. Organic production packages will be more locationspecific than inorganic package of practices as the input use depends largely on locally available resources.

- Identification of suitable varieties from existing pool for optimum productivity, quality and pest resistance

- Understand the nutrient release patterns of different organic sources in combination and alone.

- Development of cost effective technologies for on-farm organic manure production as well as large-scale production of compost from domestic, agricultural, and industrial wastes.

- Development of appropriate machines, tools and machine or bullock driven devices for organic farming operations such as manure spreader, mechanical weeding machines, seed drills for multi-crop sowing and planting etc.

- Generation of adequate scientific information on the yield, quality, economics and post-harvest aspects of various crops under different management levels and agro-climatic conditions.

- Study the role organic agriculture in mitigating the climate change and the potential of organic farming to adapt to climate change

- Developing methods which link production systems to product quality and onwards into both livestock and human health and well-being.

\section{Conclusion}

There has been significant increase in the area under certified organic farming during the last 10 years. With less than 42,000 ha under certified organic farming during 2003-04, the area under organic farming grew by almost 25 fold, during the next 5 years, to 1.2 million ha during 2008-09. It is evident from limited short-term research findings that many crops respond better to organic management particularly after an initial conversion period of 2-3 years. Organic farming can significantly contribute to improving the livelihoods of small holders as it generates higher incomes and involves less risk.

\section{References}

Dubey, Y.P., Datt, N., 2014. Influence of organic, inorganic and 
integrated use of nutrients on productivity and quality of pea (Pisum sativum) vis-à-vis soil properties. Indian Journal of Agricultural Sciences 84(10), 1195-1200.

Eyhorn, F., Mader, P., Ramakrishnan, M., 2009. The impact of organic cotton farming on the livelihoods of smallholders: Evidence from the Maikaal BioRe project in Central India. Organic Farming Newsletter 5(1), 19-21.

Gill, M.S., Prasad, K., 2009. Network Project on Organic Farming-Research highlights. Organic Farming Newsletter 5(2), 3-10.

Gopinath, K.A., Supradip Saha, Mina, B.L., 2011. Effects of organic amendments on productivity and profitability of bell pepper-french bean-garden pea system and on soil properties during transition to organic production. Communications in Soil Science and Plant Analysis 42(21), 2572-2585.

Gopinath, K.A., Supradip Saha, Mina, B.L., Kundu, S., Harit Pande, Gupta, H.S., 2008. Influence of organic amendments on growth, yield and quality of wheat and on soil properties during transition to organic production. Nutrient Cycling in Agroecosystems 82, 51-60.

Howard, A., 1943. An Agricultural Testament. The Oxford University Press, Oxford, 243.

Mahale, P., Soree, H., 1999. Ancient visions and new experiments of rural people. In: Food for Thought. India Books for Change, Bangalore.

Panneerselvam, P., Hermansen, J.E., Halberg, N., 2011. Food security of small holding farmers: Comparing organic and conventional systems in India. Journal of Sustainable Agriculture 35, 48-68.
Partap, T., Vaidya, C.S., 2009. Organic farmers speak on economics and beyond. Westville Publishing House, New Delhi, 161.

Pereira, W., 1993. Tending the Earth. Earthcare Books, Mumbai, 315.

Ramanjaneyulu, A.V., Sarkar, N.C., Thakur, A.K., Maiti, R.K., 2013. Organic farming - A perspective. International Journal of Bio-resource and Stress Management 4(3), i-ii.

Ramesh, P., Panwar, N.R., Singh, A.B., Ramana, S., Yadav, S.K., Shrivastava, R., Subba Rao, A., 2010. Status of organic farming in India. Current Science 98(9), 1190-1194.

Randhawa, M.S., 1986. A History of Agriculture in India 19801986, Vol. I-IV, Indian Council of Agricultural Research, New Delhi.

Saha, S., Mina, B.L., Gopinath, K.A., Kundu, S., Gupta, H.S., 2008. Relative changes in phosphatase activities as influenced by source and application rate of organic composts in field crops. Bioresource Technology 99, 1750-1757.

Surekha, K., Rao, K.V., Shobha Rani, N., Latha, P.C., Kumar, R.M., 2013. Evaluation of organic and conventional rice production systems for their productivity, profitability, grain quality and soil health. Agrotechnology, S11: 006. doi:10.4172/2168-9881.S11-006.

Willer, H., Julia, L., 2014. The World of Organic Agriculture Statistics and Emerging Trends 2014. Research Institute of Organic Agriculture (FiBL), Frick, and International Federation of Organic Agriculture Movements (IFOAM), Bonn, 302. 